\title{
ПСИХОЛОГІЧНІ ОСОБЛИВОСТІ СОЦІАЛІЗАЦІЇ ТА СПІЛКУВАННЯ ДІТЕЙ ДОШКІЛЬНОГО ВІКУ ІЗ ЗАГАЛЬНИМ НЕДОРОЗВИНЕНИМ МОВЛЕННЯМ III РІВНЯ
}

\section{Андрейко Богдана Володимирівна}

Кандидат психологічних наук, доцент кафедри спеціальної освіти та сочіальної роботи Львівського національного університету ім. I. Франка, м. Львів (Украӥна)

ORCID ID: https://orcid.org/0000-0002-6303-6647

\section{Дмитрів Юлія Миколаївна}

Бакалавр факультету педагогічної освіти Львівського національного університету ім. Івана Франка, м. Львів (Украӥна)

ORCID ID: https://orcid.org/0000-0002-8195-963X

\begin{abstract}
Анотація. У наш час в освітніх закладах перебуває велика кількість дітей із порушеннями мовлення, в яких присутні вторинні порушення в пізнавальній діяльності, емоційновольовій сфері, у поведіниі. Проте, найчастіше у таких дітей спостерігаються в першу чергу порушення сочіалізаџії та спілкування. Діти з особливими освітніми потребами, з порушеним психофізичним розвитком, з мовленнєвими порушеннями, перебуваючи в інклюзивному середовищі, у навчально-реабілітаційному центрі, чи у загальноосвітньому навчальному закладі, знаходяться там на самоті. Часто усвідомлюючи власні особливості вони не бажають входити у колектив, розуміючи щцо з ними щуось «не так», вони «не такі» як інші діти, вони виглядають по-іншому, їм потрібно більше часу для засвоєння матеріалу, а їх мовлення виділяється серед однолітків. Проте, кожна дитина є особливою, у кожної дитини є певний ресурс, завдяки якому вчитель, корекиійний педагог та інші фахівияі зможуть допомогти їй соціалізуватись та навчать ї̈ спілкуватись $i$ взаємодіяти з іншими дітьми. Педагог має виступати прикладом для наслідування серед дітей, бути зразком мовленнєвої діяльності та поведінки. Також потрібно пам'ятати і про невід'ємну роль батьків у корекційно-виховній роботі із дитиною з порушеннями. Слід залучати батьків у активний корекційний процес, адже робота батьків $\epsilon$ запорукою успішної та ефективної соціалізації та комунікації їх дітей. Ефективність корекцї процесів соціалізацї та спілкування дітей із ЗНМ ІІІ рівня, визначається, в периу чергу, ступенем результативності логопедичної
\end{abstract}


роботи над усіма сферами мовленнєвої діяльності: лексикою, граматикою, звуковимовою фонетико-фонематичними процесами та зв'язним мовленням. Проте, вже в процесі проведення логопедичних занять необхідно пропрацьовувати $i$ спілкування дитини, $i$ працювати над ї̈ сочіалізацією. Важливо помітити особливості емоційно-вольової сфери дитини з мовленнєвими порущеннями психологом, з метою підвищення самооцінки, зниження рівня тривожності, подолання замкненості у спілкуванні та соціальних взаєминах з іншими дітьми.

Ключові слова: соціалізація, спілкування, комунікащія, загальне недорозвинення мовлення, дошкільний вік.

Постановка проблеми. У зв'язку зі збільшенням кількості дітей із порушеннями мовлення, в тому числі із загальним недорозвиненням мовлення (далі - 3НМ) [15, с. 3], все більше стає помітно, як важко цим дітям пристосуватись до соціуму, навчитись взаємодіяти 3 іншими дітьми, 3 педагогами, що підтверджує актуальність даного дослідження. Для ефективного навчання та виховання дітей із ЗНМ III рівня, необхідно виділити психологічні особливості соціалізації та спілкування даної групи дітей. Некомпетентність педагогів та батьків стосовно особливостей дитини, утруднює у неї розвиток процесів соціалізації та комунікації, що в подальшому може призвести до соціальної дезадаптації, замкненості в собі, небажання розповідати про свої проблеми, підвищення рівня тривожності та зниження самооцінки. Дуже важливо вчасно попередити початок процесу дезадаптації дитини, навчити iï комунікувати та зав'язувати дружні стосунки з іншими дітьми.

Аналіз досліджсен та публікацій. Проведені численні дослідження із вивчення проблеми соціалізації та комунікації у дітей із порушеннями мовлення через призму особистості дитини (I. В. Мартиненко, А. М. Богуш, I. С. Марченко, А. М. Лемещук, В. В. Тарасун, Є. Ф. Соботович, В. В. Тищенко, М. К. Шеремет, В. М. Синьов, К. О. Островська та ін.), які дали підгрунтя для створення різноманітних корекційних програм, що характеризуються високою ефективністю.

У наукових доробках спеціальних психологів, логопедів (I. С. Марченко, І. В. Мартиненко, Н. Г. Пахомова, Н. В. Савінова, Л. І. Трофименко) зазначено, що головним критерієм мовленнєвого розвитку дітей дошкільного віку із порушеннями мовлення, зокрема із ЗНМ є комунікативні вміння. Незважаючи на велику кількість праць та досліджень у сфері мовленнєвих порушень, проведення спеціальних досліджень в галузі соціалізації та комунікації дітей дошкільного віку iз порушеннями мовлення почалось лише кілька років тому.

Мета написання статmі: подати науково-практичне обгрунтування та контастатувати особливості процесів соціалізації та спілкування дітей дошкільного віку із ЗНМ III рів- 
ня.

В процесі дослідження ми використали такі методи дослідження, як аналіз спеціальної психологічної та логопедичної літератури, спостереження, анкетування. Для того, щоб з'ясувати, як процеси соціалізації та спілкування пов’язані з рівнем тривожності, інтересу до однолітків, ініціативністю, емоційномімічними засобами спілкування та статтю, у нашому дослідженні ми використали статистичні методи, а саме - кореляційний аналіз, та встановили низку кореляційних взаємозв'язків.

Виклад основного матеріалу. Людина - соціальна істота, яка включена $з$ початку свого життя в соціум, а, отже, і в соціальну взаємодію. Розвиток людини, іiі індивідуальність та прогрес залежить не лише від біологічних чинників, а в першу чергу від законів, які прийняті в її соціальній групі. Завдяки цьому, особистість має змогу адаптовуватись, розвиватись та вдосконалюватись.

На думку багатьох вчених (Л. Божович, Л. Виготський, Д. Ельконін та ін.), найважливішим періодом в становленні соціалізованої особистості $є$ перші роки життя дитини. В цей час формуються основи для іiі особистісного, інтелектуального, соціального та педагогічного розвитку, закладаються основи іiї самосвідомості та уявлень про навколишній світ [2, с. 17].

Велика кількість вчених стверджує, що перші роки в житті людини є надзвичайно ва- жливими для її соціального, інтелектуального та особистісного розвитку [4, с. 452]. Саме в дитячому віці формуються свідомість та самосвідомість, закладаються стійкі форми міжособистісної взаємодії - моральні та соціальні норми. Соціалізація є надзвичайно важливим процесом, бо саме він визначає рівень адаптивності дитини у подальшому житті.

Процес соціалізації дошкільників вважається основною проблемою у дошкільній педагогіці та психології, адже те наскільки успішно дитина зможе іiі розв'язати, настільки повноцінно іiі особистість зможе функціонувати у соціумі. Гармонійність розвитку дитини дошкільного віку залежить від ступеня соціалізації, від засвоєння норм та правил, які необхідні для того, щоб стати повноцінним членом соціального середовища.

Якщо говорити про передумови, методи і шляхи організації процесу соціалізації дитини дошкільного віку необхідно врахувати залежність від віку, соціальної ситуації розвитку та провідної діяльності індивіда. Не слід забувати і про те, що засвоєння даного процесу дитиною, залежить не лише від навчальновиховного процесу в закладі дошкільної освіти, але і від виховного процесу та психологічного клімату в сім'ї.

Проблема соціалізації дітей із загальним недорозвиненням мовлення в умовах дошкільного навчального закладу розглядається як формування особистості дитини в системі соціальних взаємин в різних соціальних ситуа- 
ціях, адже це саме той період, коли в дитини формуються соціальні якості, знання, вміння та навички, що дають їй змогу стати дієздатним учасником соціальних відносин, формується свідомість та самосвідомість про навколишній світ через спілкування 3 близькими дорослими та ровесниками, важливо не допустити, щоб такий важливий процес як соціалізація особистості проходив без допомоги кваліфікованого педагога.

Аналіз наукової літератури 3 вищезгаданої проблеми дав змогу виокремити, що соціалізація дітей із загальним недорозвиненням мовлення є системним поняттям, що включає так званий емоційно-вольовий критерій із показниками: емоційні реакції на особливості свого мовлення; здатність до співпереживання стосовно інших дітей із порушеннями мовлення; вимогливість до себе, саморегуляція, впевненість у своїх силах [5, с. 28].

Дослідники виділяють такі психологічні особливості в емоційно-вольовій сфері, що притаманні дітям із порушеннями мовлення, зокрема із ЗНМ III рівня [5, с. 29]:

тривожність: діти емоційно вразливі, плаксиві, бояться спілкуватися;

замкнутість: діти відсторонені від однолітків i дорослих внаслідок нерозуміння оточуючими їхнього мовлення;

невпевненість у власних силах: діти переживають свою неспроможність зрозуміти повноцінно інструкцію і впоратися 3 певним завданням внаслідок заниженої самооцінки; негативізм, який проявляється неврівноваженістю, підвищеною дратівливістю, впертістю;

дитячі страхи, які виникають через стресову ситуацію.

Розлади емоційної сфери у дітей 3 порушенням мовлення негативно впливають на їх соціалізацію, чим зумовлюють порушення поведінки, так званої соціальної дезадаптації. Переживання байдужості або негативне ставлення до себе роз'єднують дітей, поглиблюють між ними відчуження, небажання спілкуватися, контактувати з однолітками.

Особливість соціалізації в дошкільному віці полягає у суттєвому ускладненні та розширенні сфери соціалізуючих впливів, які реалізуються не тільки через взаємодію 3 дорослим, але й через активну ігрову діяльність 3 ровесниками. Варто підкреслити, що ігровій діяльності дошкільників 3 порушенням мовлення притаманна не тільки змістова бідність, а й недостатньо правильна структура мовлення, яку вони використовують у грі. Спілкування, все більше набуваючи рис комунікативної діяльності, оформлюється в найбільш потужний соціальний фактор становлення особистості дитини. Вона здобуває досвід формування відносин, які в свою чергу, закладають підвалини для становлення самопізнання і самооцінки, для розвитку мотиваційних структур соціальної поведінки через спілкування 3 ровесниками $[10$, с. 156]. У складному комплексі порушень розвитку при недорозвиненні 
мовлення відзначаються не тільки відставання у формуванні мовних здібностей, але частіше за все - рухові, сенсорні, інтелектуальні порушення, несформованість пізнавальних можливостей. В міру специфіки мовленнєвого порушення, соціальний розвиток дітей не формується належним чином. Механізм соціалізації дітей із порушеннями мовлення, в тому числі із ЗНМ, має певні свої особливості. В залежності від типу мовленнєвого порушення, діти відчувають труднощі в засвоєнні системи культури мови і зразків поведінки у суспільстві. В них відзначається утруднення взаємодії із соціальним середовищем, знижена здібність до адекватного реагування на зміни, що відбуваються. Їм складно досягати своїх цілей, що може призвести до дисбалансу в поведінці [6, c. 115].

Дослідження, проведені вченими, виявили, що для дітей із загальним недорозвиненням мовлення характерним є наступне: недостатня комунікабельність, невміння встановлювати і розвивати емоційні зв'язки, зниження наслідувальної діяльності, самостійності, низький рівень сформованості навичок самообслуговування, нестійкість уваги, знижений рівень мотивації, підвищена психічна виснажливість, стомлюваність, порушення поведінки. Через несформованість репродуктивної фази монологічного мовлення, діти 3 системними порушеннями мовлення здебільшого не ставлять запитань про зміст прочитаного, не здатні переказати те, що почули. Навіть якщо під час бесіди 3 дорослим дитина й переходить до діалогу, то постійно змінює одну тему на іншу. Можна вказати на нестійкість пізнавального інтересу, через це діалог триває зазвичай не більше 7-8 хвилин [9, с. 325].

Аналіз спеціальної наукової літератури показав, що в умовах загального недорозвинення мовлення III рівня необхідні мовленнєві контакти, які включаються в діяльність дитини, зводяться до мінімуму. Практична діяльність і поведінка залишаються невербалізованими i неусвідомленими. Така розірваність несе в собі дві небезпеки: з однієї сторони, формування певної «мовленнєвої ситуативності», коли дитина спілкується 3 дорослим в межах вже існуючих «мовленнєвих штампів», 3 іншої - затримка на межі вже існуючих «мовленнєвих штампів», що призводить до несвідомої, мимовільної поведінки. Своєчасний розвиток необхідних компонентів соціальної поведінки у дітей гальмується недостатнім рівнем розвитку мовлення, що сприяє появі емоційно-вольових, особистісних та поведінкових труднощів. Порушення вимови, як один із елементів загального недорозвинення мовлення, негативно позначаються на формуванні характеру дитини, а якщо порушення системне, то це може призвести до того, що дитина замкнеться в собі, перестане спілкуватись і розмовляти. Якщо вчасно не провести корекційну роботу, то таке порушення може ускладнитись та стати стійким, і $є$ висока ймовірність, що у дитини на етапі шкільного нав- 
чання 3'являться специфічні порушення читання та письма (дислексія і дисграфія). Порушення писемного мовлення, які можуть стати у молодшому шкільному віці вторинними, легше попередити у дошкільному. Тому доцільним $є$ проведення корекційних занять логопедом [4, с. 452]. Одним із напрямків роботи вчителя-логопеда є просвітницька діяльність із батьками. Вони отримують всі необхідні рекомендації і дидактичні матеріали. Така спільна робота дозволяє батькам брати участь у корекційно-розвивальній роботі і бачити динаміку розвитку мовлення своїх дітей.

Від рівня комунікативного розвитку дитини залежить успішність соціальнопсихологічної адаптації в суспільстві та самореалізації можливостей і умінь. Також, вчені відзначають, що недостатній рівень комунікативної готовності дітей переростає у труднощі в спілкуванні, які важко подолати в процесі навчання і виховання [9, с. 321]. Це означає, що без цілеспрямованого і систематичного формування комунікативних компонентів згодом у дитини ймовірно 3'являться негативні індивідуальні особливості, які важче піддаються корекції. Відставання в розвитку мовлення, незрілість дитини супроводжується затримкою певних психічних функцій, емоційною нестійкістю в поведінці. Все це створює складності комунікативного процесу, i, як наслідок, відбувається гальмування розвитку комунікативних навичок у дошкільників.

Комунікативно-мовленнєвий розвиток $\epsilon$ важливим чинником у розвитку особистості та процесі іiї соціалізації. Прагнення вихователя залучати дітей дошкільного віку до комунікативно-мовленнєвої діяльності дає змогу забезпечити повноцінне функціонування у соціумі, закладає підвалини соціального досвіду, що дасть можливість насолодитися власною мовленнєвою особистістю у дорослому віці. Виховання - це основний шлях до формування комунікативно-мовленнєвих мотивів дошкільника. Серед чинників, що впливають на мовленнєву діяльність, комунікацію і спілкування, є система мовленнєвих мотивів.

Мовлення як засіб спілкування є першим видом соціальної активності, завдяки якому дитина отримує ,необхідну для ii індивідуального розвитку, інформацію. Відповідно до поглядів вітчизняних психологів (Л.С. Виготський, О.В. Запорожець, О.Н. Леонтьєв, С.Л. Рубінштейн, І.В. Мартиненко та ін.), спілкування виступає в якості однієї з основних умов нормального розвитку дитини, найважливішого чинника формування його особистості, і нарешті, провідного виду людської діяльності, спрямованої на пізнання та оцінку самого себе за посередництвом інших людей. Однією з умов формування повноцінної особистості дитини, гармонійного психофізичного розвитку, успішного навчання іiі в школі $\epsilon$ своєчасне оволодіння правильним мовленням і активне користування ним у спілкуванні [8, c. 159].

У своїх дослідженнях Sherratt D., Peter 
М. виявили, що ефективність комунікації у дитини визначається сукупністю наступних параметрів [7, с. 288]:

здатністю розуміти і використовувати рухи тіла в процесі комунікативної ситуації (мова тіла, міміка, жести);

наявністю комунікативної підтримки, що включає в себе об'єкти, про які йде мова (фотографії, картинки);

умінням використовувати мову і вокалізації та володіти інтонаційною виразністю.

Дослідження спілкування дітей дошкільного та молодшого шкільного віку із ЗНМ в ігровій діяльності (Грибова О.Є., Гриншпун Б.М., Соловйова Л.Г., Харитонова П.А., Чиркіна Г.В., Шипіцина Л.М.) засвідчили: низьку мовленнєву активність дітей у грі, недостатній мовленнєвий супровід ігрових дій; труднощі ведення діалогу на тематику, що не стосується побутових ситуацій; незацікавленість в контакті, дезорієнтація в нових ситуаціях спілкування. Відповідно до наукових висновків, недостатність вербальних засобів утруднює процес взаємодії між дітьми в ігровій діяльності. Крім системних порушень мовлення, у дітей із ЗНМ затримується розвиток психічних проце- сів, не формуються навички комунікації. Все це не сприяє розвитку мовленнєво- мисленнєвої та пізнавальної діяльності та не дозволяє набути процесу спілкування двобічного характеру [13, с. 47].

Здійсненню повноцінного спілкування перешкоджають бідність та недиференційованість словникового запасу, недостатність дієслівного словника, недосконалість зв'язного мовлення. Зазначені особливості розвитку мовлення знижують потребу у спілкуванні. Окрім цього, у таких дітей наявні особливості поведінки: спостерігається негативізм. Діти не зацікавлені в контактах, не орієнтуються в ситуації спілкування [7, с. 289].

Дошкільники із ЗНМ III рівня не дотримуються норм та правил спілкування 3 дорослими та однолітками, тобто у них наявна не сформованість самої культури спілкування. Це явище можна побачити у випадках безцеремонності у розмові з дорослим, відсутності почуття дистанції, підвищених інтонаціях.

В результаті досліджень вченими встановлено, що для більшості дошкільників із порушенням мовлення характерна здатність вступати в контакт лише за зовніш-

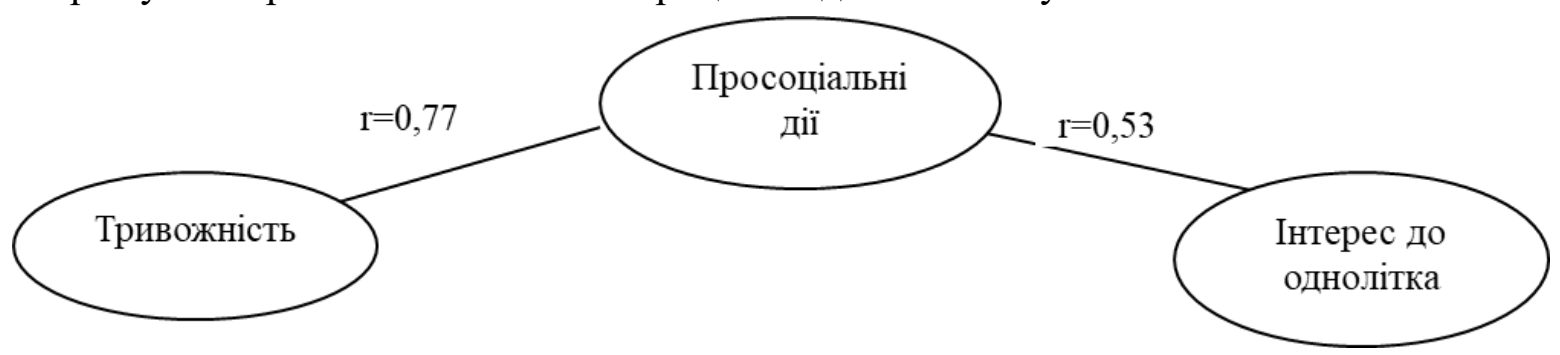

Рис.1. Взасмозв'язок тривожності, просоціальних дій та інтересу до однолітка 
ньою ініціативою та зниження інтересу до спілкування. Такі діти потребують налагодження емоційного контакту з дорослим, формування зацікавленості у спілкуванні з дітьми та близькими дорослими. Чимало науковців зійшлись на думці, що активному комунікативному розвитку передує потреба у спілкуванні, прагнення вступати в контакт з однолітками та близькими дорослими $[11$, с. 60$]$.

Для того, щоб виявити зв'язки між процесами соціалізації та спілкування, а також між рівнем самооцінки та тривожності, було проведено кореляційне дослідження. За результатами дослідження виявлено три прямі кореляційні взаємозв'язки та один обернений

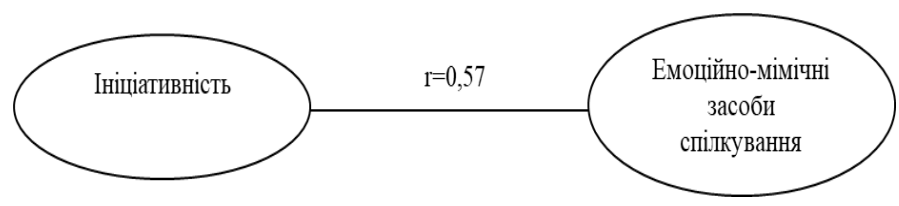

\section{Рис.2. Взаємозв'язок між ініціативністю та тривожністю}

взаємозв'язок.

Виявлено прямий кореляційний взаємозв'язок (рис.1) між показниками тривожність та просоціальні дії (r=0,77), низький piвень тривожності сприяє здатності дитини враховувати бажання однолітка, уміння поділитися чимось, допомогти, робити щось разом. Також виділено прямий кореляційний взаємозв'язок (рис.1) між показниками просоціальні дії та інтерес до однолітка $(\mathrm{r}=0,53)$, a саме до спілкування та взаємодії з ним, що

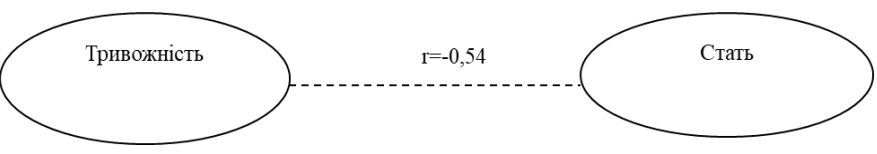

\section{Рис.3. Взаємозв'язок між тривожністю та статтю}

свідчить про те, чим більша залученість дитини в спільну діяльність 3 іншими дітьми і зацікавленість у ній, тим більша ймовірність того, що діти будуть продуктивно взаємодіяти, 3 користю один для одного.

Встановлено прямий кореляційний взаємозв'язок між ініціативністю та емоційномімічними засобами мовлення $(\mathrm{r}=0,57)$, чим більш ініціативною є особистість дитини, тим більш емоційно забарвленими є дії дітей, розкутість відносно однолітків, активна взаємодія між ними (рис.2).

За результатами дослідження , виявлено обернений кореляційний зв'язок між показниками тривожність та стать $(\mathrm{r}=-0,54)$, який пояснюється тим, що дівчатка менш схильні до підвищеного рівня тривожності, а хлопчики - навпаки. Це може пояснюватись тим, що хлопці більш критично сприймають власні порушення мовлення, відчувають певний дискомфорт, а дівчата - намагаються не зважати на певні мовленнєві недоліки у їх мовленні й не настільки переживають через них (рис.3).

Висновки. Отже, у дітей дошкільного віку із ЗНМ III рівня наявні особливості процесу соціалізації та спілкування. Через те, що у дитини є порушення мовлення, а саме збіднений словник, недотримання граматичних 
норм мови, порушення звуковимови, фонетико-фонематичних процесів та зв'язного мовлення, налагодження стосунків у дитячому колективі, обмін інформацією відбувається неповною мірою. Звідси у дітей з'являється підвищена тривожність, знижується інтерес до однолітків, ініціативність у взаєминах з ними, втрачається емоційна забарвленість у спілкуванні.

Для дітей чи то з нормотиповим розвитком чи 3 порушеннями мовлення , що проходить етап соціалізації, ідеалом соціального середовища $є$ сім'я, освітній заклад, соціум. Дитина переходить з однієї соціальної групи в іншу, що, безумовно, впливає на розвиток процесу соціалізації. Відповідно, соціальне середовище може сприяти даному процесу або гальмувати його. За умов, які відповідають потребам дитини, результат соціалізації характеризується високою ефективністю. За несприятливих умов, процес соціалізації набуває рис нестабільності, не комфортності, мало ефективності. Тому дитина зможе успішно пройти всі етапи лише за умови наявності двостороннього процесу взаємодії, відповідного соціального середовища, цілеспрямованого навчання та виховання, як в сім'ї так і в навчальному закладі.

Серед особливостей соціалізації дітей дошкільного віку із ЗНМ III рівня можна виділити такі як, нестійкість пізнавальних інтересів, недостатня залученість дитини у ігрову діяльність, порушення зв'язного мовлення, порушення процесу адаптації, невміння будувати відносини за допомогою вербальних засобів, поведінкові порушення, підвищена тривожність та занижена самооцінка. Проте, якщо вчасно звернутись до спеціаліста, ці всі вищезгадані особливості дитина припрацьовує із логопедом, і процес соціалізації дитини проходить більш ефективно.

Для дітей із ЗНМ III рівня характерні стійкі і виражені порушення спілкування. Наявність мовленнєвого порушення перешкоджає встановленню комунікативних зв'язків 3 оточуючими людьми, а також може призвести до ізоляції їх у групі ровесників. В зв'язку із цим потрібно проводити спеціальну корекційну роботу по цілеспрямованому розвитку спілкування у даній категорії дітей. Порушення комунікативної діяльності є однією із специфічних закономірностей розвитку у разі мовленнєвих порушеннях у дітей. У подальшому це порушення призводить до труднощів соціалізації, що суттєво позначається на соціальній ситуації розвитку індивіда.

Основною формою роботи 3 метою активізації мовленнєвої комунікації $є$ гра, як провідний вид діяльності дитини дошкільного віку. Важливо, створити емоційно насичену ситуацію, в якій дитина змогла би проявити всі свої здібності. Розвиток комунікативних навичок однозначно повинен відбуватись в процесі соціалізації, і навпаки, соціалізація відбувається в результаті мовленнєвої взаємодії дитини із оточенням. Для того, 
щоб повною мірою соціалізуватись, дитина в першу чергу має оволодіти мовленнєвою компетенцією. Результати кореляційного аналізу показали, наскільки ці поняття перебувають у тісному взаємозв'язку. Такі діти важко налагоджують контакти, їх коло спілкування є дуже малим, вони неохоче граються 3 іншими дітьми, надають перевагу іграм на самоті. В зв'язку з тим, що діти мало комунікують 3 іншими, процес соціалізації відбувається дуже повільно, і відповідно може призвести до затримки пізнавальних психічних процесів.

Перспективи подальших досліджень y даному напрямі. Соціалізація та спілкування дітей із мовленнєвою патологією є актуальним питанням для психологів, лінгвістів, логопедів, дефектологів. Складання корекційних програм та програм індивідуального розвитку вимагає дослідження процесів соціалізації та комунікації, і відповідно, включення ïx у корекційно-виховний процес дитини. Тому тематика даного дослідження $є$ основою для написання статтей та наукових робіт.

\section{Перелік використаних джерел:}

1.Бобак О.Б. Соціалізація особистості в дошкільному віці як предмет науково-педагогічного вивчення / О.Б. Бобак // Міжвузівський збірник наукових праць молодих учених Дрогобицького державного педагогічного університету імені Івана Франка. - Дрогобич : Посвіт, 2013. - Вип. 4. - С. 178-184.

2.Божович Л. И. Личность и ее формирование в детском возрасте / Л. И. Божович - СПб. [и др.]: Питер, 2008. $-398 \mathrm{c}$.
3.Вінокурова О. В. Вплив мовленнєвих порушень на особистість, поведінку та емоційно-вольову сферу диини / О. В. Вінокурова, С. М. Вінокурова // Науковий часопис Національного педагогічного університету імені М. П. Драгоманова. Серія 19: Корекційна педагогіка та спеціальна психологія / М-во освіти і науки, молоді та спорту України, Нац. пед. ун-т ім. М.П. Драгоманова. - Київ : Вид-во НПУ ім. М. П. Драгоманова, 2014. Вип. 28. - С. $37-41$

4.Гуженкова Н.В., Михайленко В.В. Активизация речевого общения детей старшего дошкольного возраста с общим недоразвитием речи / Н.В. Гуженкова, В.В. Михайленко // Молодой ученый. - Казань, Молодой ученый, 2017. - №16 (150). - С. 452-454.

5.Лемещук М.А. Емоційно-вольовий аспект соціалізації старших дошкільників із загальним недорозвиненням мовлення / М. А. Лемещук // Дослідження різних напрямків розвитку психології та педагогіки: Збірник наукових робіт учасників міжнародної науково-практичної конференції: (17- 18 червня 2016 р., м. Одеса). - Одеса: ГО «Південна фундація педагогіки», 2016. - 104 с.

6.Лемещук М.А. Проблеми соціалізації дошкільників із загальним недорозвиненням мовлення в емоційновольовій сфері / М.А. Лемещук // Збірник наукових праць Херсонського державного університету. Педагогічні науки. - 2016. - Вип. 69 (3). - С. 115-118.

7.Мартиненко I.В. До проблеми порушень комунікації у дітей із тяжкими порушеннями мовлення / I.B. Мартиненко // Науковий часопис НПУ імені М.П.Драгоманова. Серія 19. Корекційна педагогіка та спеціальна психологія. Зб. наукових праць. - К.: НПУ імені М.П.Драгоманова, 2010. - № 16. - С. 288-290.

8.Мартиненко I. В. Особливості вольової готовності до шкільного навчання дітей шестирічного віку із загальним недорозвиненням мовлення / I. В. Мартиненко // Науковий часопис НПУ імені М.П. Драгоманова. Серія № 19 : Корекційна педагогіка та спеціальна психологія: Зб. наукових праць. - К. : НПУ імені М. П. Драгоманова, 2005. - № 5. - С. 159 - 164. 
9.Мартиненко І.В. Особливості міжособистісної комунікації у дітей із нормальним та порушеним мовленнєвим розвитком / I.В. Мартиненко // Науковий часопис НПУ імені М.П. Драгоманова. Серія 19: Корекційна педагогіка та спеціальна психологія. - 2013. - Вип. 24. - C. 321-325.

10.Марченко І.С., Пузир Т.Ю. Активізація мовленнєвого спілкування дітей із загальним недорозвиненням мовленням / І.С. Марченко, Т.Ю. Пузир // Збірник наукових праць Кам'янець-Подільського національного університету імені Івана Огієнка. Серія: Соціальнопедагогічна. - 2010. - Вип. 15. - С. 156-160.

11.Мартинчук О.В. Активізація мовленнєвої діяльності дітей раннього віку в освітньому просторі дошкільного навчального закладу / О.В. Мартинчук // Психолінгвістика. - 2011. - Вип. 8. - С. 59-65.

12. Островська К.О. Засади комплексної психологопедагогічної допомоги дітям з аутизмом : монографія / К. О. Островська. - Львів : «Тріада плюс», 2012. - 520 c.

13. Соловьева Л. Г. Особенности коммуникативной деятельности детей с общим недоразвитием речи // Дефектология. - 1996. - № 1 .

14. Трофименко Л. І. Діагностика та корекція загального недорозвитку мовлення у дітей дошкільного віку: Навч.-метод. посібн. / Л. І. Трофименко. - Київ: Інститут спеціальної педагогіки НАПН України, 2014. - 72 с.

15. Трофименко Л. І. Корекційне навчання з розвитку мовлення дітей старшого дошкільного віку із ЗНМ / Л. I. Трофименко. - Київ: «Актуальна освіта», 2013. - 108 c.

\section{References (Transliteration):}

1.Bobak O.B. Sotsializatsiya osobistosti v doshkilnomu vitsi yak predmet naukovo-pedagogichnogo vivchennya / O.B. Bobak // MIzhvuzivskiy zbIrnik naukovih prats molodih uchenih Drogobitskogo derzhavnogo pedagogichnogo universitetu imeni Ivana Franka. Drogobich : Posvit, 2013. - Vip. 4. - S. 178-184.
2.Bozhovich L. I. Lichnost i ee formirovanie $\mathrm{v}$ detskom vozraste / L. I. Bozhovich - SPb. [i dr.]: Piter, 2008. - 398 S.

3.VInokurova O. V. Vpliv movlennevih porushen na osobistist, povedinku ta emotsIyno-volovu sferu diini / O. V. VInokurova, S. M. VInokurova // Naukoviy chasopis NatsIonalnogo pedagogIchnogo unIversitetu imeni M. P. Dragomanova. SerIya 19: KorektsIyna pedagogIka ta spetsIalna psihologIya / M-vo osviti I nauki, molodi ta sportu UkraYini, Nats. ped. un-t Im. M.P. Dragomanova. KiYiv : Vid-vo NPU Im. M. P. Dragomanova, 2014. - Vip. 28. - C. $37-41$.

4.Guzhenkova N.V., Mihaylenko V.V. Aktivizatsiya rechevogo obscheniya detey starshego doshkolnogo vozrasta s obschim nedorazvitiem rechi / N.V. Guzhenkova, V.V. Mihaylenko // Molodoy uchenyiy. Kazan, Molodoy uchenyiy, 2017. - \#16 (150). - S. 452454.

5.Lemeschuk M.A. EmotsIyno-voloviy aspekt sotsializatsiyi starshih doshkilnikiv iz zagalnim nedorozvinennyam movlennya / M. A. Lemeschuk // Doslidzhennya riznih napryamkiv rozvitku psihologiyi ta pedagogiki: Zbirnik naukovih robit uchasnikiv mizhnarodnoyi naukovo-praktichnoyi konferentsiyi: (1718 chervnya 2016 r., m. Odesa). - Odesa: GO «Pivdenna fundatsIya pedagogIki», 2016. - $104 \mathrm{~s}$.

6.Lemeschuk M.A. Problemi sotsIalIzatsIYi doshkIlnikIv iz zagalnim nedorozvinennyam movlennya $\mathrm{v}$ emotsIynovolovIy sferi / M.A. Lemeschuk // ZbIrnik naukovih prats Hersonskogo derzhavnogo unIversitetu. PedagogIchnI nauki. - 2016. - Vip. 69 (3). - S. 115-118.

7.Martinenko I.V. Do problemi porushen komunikatsiyi u ditey iz tyazhkimi porushennyami movlennya / I.V. Martinenko // Naukoviy chasopis NPU imeni M.P.Dragomanova. Seriya 19. KorektsIyna pedagogika ta spetsialna psihologiya. Zb. naukovih prats. - K.: NPU imeni M.P.Dragomanova, 2010. - \# 16. - S. 288-290.

8.Martinenko I. V. Osoblivosti volovoyi gotovnosti do shkilnogo navchannya dItey shestirIchnogo viku iz zagalnim nedorozvinennyam movlennya / I. V. 
Martinenko // Naukoviy chasopis NPU ImenI M.P. Dragomanova. Seriya \# 19 : Korektsiyna pedagogika ta spetsialna psihologiya: Zb. naukovih prats. - K. : NPU imeni M. P. Dragomanova, 2005. - № 5. - S. 159 - 164.

9.Martinenko I.V. Osoblivosti mizhosobistisnoyi komunikatsiyi $\mathrm{u}$ ditey iz normalnim ta porushenim movlennevim rozvitkom / I.V. Martinenko // Naukoviy chasopis NPU imeni M.P. Dragomanova. Seriya 19: Korektsiyna pedagogika ta spetsialna psihologiya. - 2013. - Vip. 24. - S. 321-325.

10.Marchenko I.S., Puzir T.Yu. AktivIzatsIya movlennevogo spilkuvannya ditey iz zagalnim nedorozvinennyam movlennyam / I.S. Marchenko, T.Yu. Puzir // ZbIrnik naukovih prats Kam'yanets-PodIlskogo natsIonalnogo unIversitetu imeni Ivana Ogienka. SerIya: Sotsialno-pedagogichna. - 2010. - Vip. 15. - S. 156-160.

11.Martinchuk O.V. Aktivizatsiya movlennveoyi diyalnosti ditey rannogo viku $\mathrm{v}$ osvitnomu prostori doshkilnogo navchalnogo zakladu / O.V. Martinchuk // Psiholingvistika. - 2011. - Vip. 8. - S. 59-65.

12. Ostrovska K.O. Zasadi kompleksnoyi psihologopedagogIchnoyi dopomogi dityam $\mathrm{z}$ autizmom : monografiya / K. O. Ostrovska. - Lviv : «Triada plyus», 2012. - $520 \mathrm{~s}$.

13. Soloveva L. G. Osobennosti kommunikativnoy deyatelnosti detey $\mathrm{s}$ obschim nedorazvitiem rechi // Defektologiya. — 1996. - № 1 .

14.Trofimenko L. I. Korektsiyne navchannya $\mathrm{z}$ rozvitku movlennya ditey starshogo doshkilnogo viku iz ZNM / L. I. Trofimenko. - Kiyiv: «Aktualna osvita», 2013. - 108 s.

15.Trofimenko L. I. Korektsiyne navchannya $\mathrm{z}$ rozvitku movlennya ditey starshogo doshkIlnogo viku iz ZNM / L. I. Trofimenko. - Kiyiv: «Aktualna osvita», 2013. - 108 s.

\section{Andreiko Bohdanya}

PhD (Psychology), the associate professor of the department of Corrective pedagogy and Inclusion of Ivan Franko National University of Lviv, Lviv (Ukraine)

\section{Dmytriv Yuliia}

Bachelor of the department of Corrective pedagogy and Inclusion of Ivan Franko National University of Lviv, Lviv (Ukraine)

\section{PSYCHOLOGICAL FEATURES OF SOCIALIZATION AND COMMUNICATION OF PRESCHOOL CHILDREN WITH THE $3^{\text {RD }}$ LEVEL OF GENERAL UNDERDEVELOPMENT OF SPEECH}

\section{ABSTRACT}

Nowadays, there are a large number of children with speech disorders in educational institutions, in which there are secondary violations in cognitive activity, emotionally-volitional sphere and in behavior. However, mostly in such children there are primarily violations of socialization and communication. Children,with special educational needs, with disturbed psychophysical development or speech disorders, staying in an inclusive environment, in a educationalrehabilitation center, or in a secondary school, are there with themselves. Often, realizing their own features, they do not want to join the group, realizing that something "wrong" with them, they are "not like" other children, they look differently, they need more time to master the material, and their speech is distinguished by coevals. However, each child is special, each child has a certain resource through which a teacher, 
correction teacher and other specialists will be able to help her socialize and teach her to communicate and interact with other children. It is also necessary to remember the paramount role of parents in correctional and educational work with a child with violations. The teacher should act as an example for imitation among children, to be a model of speech activity and behavior. Parents should be involved in the active correction process, since the work of parents is the key to the successful and effective socialization and communication of their children. The effectiveness of correction of the processes socialization and communication of children with the $3^{\text {rd }}$ level of general underdevelopment of speech is determined, first of all, by the degree of effectiveness of speech therapy work on all spheres of speech activity: vocabulary, grammar, sound phonemicphonematic processes and coherent speech. However, already in the process of conducting speech therapists it is necessary to work out communication of the child, and work on its socialization. It is important to note the peculiarities of the emotional and volitional sphere of the child with speech disorders by the psychologist, in order to increase self-esteem, reduce anxiety, overcome secrecy in communication and social relationships with other children.

Key words: socialization, intercourse, communication, general underdevelopment of speech, preschool age.

\section{Андрейко Богданна Володимировна}

Кандидат психологических наук, доцент кафедры спеичиального образования и сочиальной работь Львовского національного университета им. И. Франко, г. Львов (Украина)

\section{Дмитрив Юлия Николаевна}

Бакалавр кафедры специиального образования и соииальной работь Львовского національного университета им. И. Франко, г. Львов (Украина)

\section{ПСИХОЛОГИЧЕСКИЕ ОСОБЕННОСТИ СОЦИАЛИЗАЦИИ И ОБЩЕНИЯ ДЕТЕЙ ДОШКОЛЬНОГО ВОЗРАСТА С ОНР ІІІ УРОВНЯ}

Аннотация. В наше время в образовательных учреждениях находится большое количество детей с патологией речи, в которых присутствуют вторичные нарушения в познавательной деятельности, эмоциональноволевой сфере, в поведении. Однако, чаще всего у таких детей наблюдаются в первую очередь нарушение социализации и общения. Дети с особыми образовательными потребностями, с нарушенным психофизическим развитием или с речевыми нарушениями, находясь в инклюзивной среде, в учебнореабилитационном центре, или в общеобразовательном учебном заведении, находятся там в одиночестве. Часто осознавая свои особенности они не желают входить в коллектив, понимая что с ними что-то «не так», они «не такие» как другие дети, они выглядят подругому, им нужно больше времени для усвоения материала, а их речи выделяется среди сверстников. Однако, каждый ребенок являет- 
ся особенным, у каждого ребенка есть определенный ресурс, благодаря которому учитель, коррекционный педагог и другие специалисты смогут помочь ей социализироваться и научат его общаться и взаимодействовать с другими детьми. Педагог должен выступать примером для подражания среди детей, быть образцом речевой деятельности и поведения. Также нужно помнить и о неотъемлемой роль родителей в коррекционно-воспитательной работе с ребенком с нарушениями. Следует привлекать родителей в активный коррекционный процесс, ведь работа родителей является залогом успешной и эффективной социализации и коммуникации их детей. Эффективность коррекции процессов социализации и общения детей с ОНР III уровня, определяется, в первую очередь, степенью результативности логопедической работы над всеми сферами речевой деятельности: лексикой, грамматикой, звукопроизношением фонетикофонематическим процессами и связной речью. Однако, уже в процессе проведения логопедических занятий необходимо прорабатывать и общения ребенка, и работать над ее социализацией. Важно заметить особенности эмоционально-волевой сферы ребенка с речевыми нарушениями психологом, с целью повышения самооценки, снижением уровня тривожности, преодоление замкнутости в общении и в социальных взаимоотношениях с детьми.
Ключевые слова: социализация, общение, коммуникация, общее недоразвитие речи, дошкольный возраст. 